DOI: $10.4274 /$ tpa.45.144

\title{
Astımlı çocukların benlik saygıları ve annelerinin duygu dişavurum düzeylerinin değerlendirilmesi
}

\section{The relationship in between self-esteem levels and the mothers' expressed emotion in children with asthma}

\author{
Sema Ölçer, Neşe Perdahlı Fiş*, Meral Berkem*, Bülent Karadağ ${ }^{* *}$ \\ Kayseri Kadın Doğum ve Çocuk Hastalıkları Hastanesi, Kayseri, Türkiye \\ *Marmara Üniversitesi Çocuk ve Ergen Ruh SağıIğı ve Hastalıkları Anabilim Dalı, İstanbul, Türkive \\ **Marmara Üniversitesi Çocuk ve Göğüs Hastalıkları Bilim Dalı, istanbul, Türkiye
}

\section{Özet}

Amaç: Bu çalışmanın amacı astımlı çocukların benlik saygılarının incelenmesi ve annelerinin duygu dışavurumu düzeyinin belirlenmesidir.

Gereç ve Yöntem: Astım tanısıyla takip edilen 65 çocuk, kronik hastalığı bulunmayan 76 çocukla karşılaştııımıştır. Psikopatoloji varlı̆̆ı Çocuklar İçin Duygulanım Bozuklukları ve Şizofreni Görüşme Çizelgesiyle, genel davranış sorunları Çocuk ve Gençler İçin Davranış Değerlendirme Ölçeğiyle değerlendirilmiştir. Ek olarak çocuklara Piers Harris Çocuklarda Öz Kavramı Ölçeği ve annelerine Duygu Dışavurum Ölçeği uygulanmıştır. Gruplar karşılaştırılırken ki-kare ve student's t testi kullanılmıştır. Değişkenler arası ilişkiler Pearson bağıntı analizi ile incelenmiştir.

Bulgular: Astımlı çocuklarda psikiyatrik tanı alma sıklığının $(p=0,00)$ ve davranış sorunlarının $(p<0,01)$ daha fazla olduğu görülmüştür. Astımlılarda benlik saygısı düzeyi kontrol grubu ile benzerlik göstermekle birlikte anne duygu dışavurumu arttıkça çocukların benlik saygısının düştüğü saptanmıştır ( $r=-0,38, p=0,002)$. Annelerin duygu dışavurum düzeyi astım grubunda daha yüksek bulunmuş ( $p=0,006)$, çocukta psikiyatrik tanı alma ve davranış sorunları sıklı̆ı ile ilişkili olduğu görülmüştür.

Çıkarımlar: Astım varlığı benlik saygısını doğrudan etkilememekle birlikte eşlik eden psikiyatrik bozukluklar, duygusal ve davranışsal sorunlar ve annenin duygu dışavurumunun fazla olması çocukta benlik saygısının azalmasına neden olmaktadır. (Türk Ped Arş 2010; 45: 144-9)

Anahtar sözcükler: Astım, çocuk, duygu dışavurumu, kendilik kavramı

\section{Summary}

Aim: The objective of this study is to evaluate the self-esteem levels of asthmatic children and the maternal emotional expressiveness.

Material and Method: Sixty-five children and adolescents with the diagnosis of asthma were compared with a control group of 76 children, without a chronic illness. Presence of psychopathology was evaluated by Kiddie-Schizofrenia Affective Disorders Schedule, behavioral problems were assessed by Child Behaviour Checklist. Additionally, Piers Harris Self- Esteem Inventory and Expressed Emotions Questionnaire were administered to children and adolescents and to their mothers, respectively. In order to compare the groups, chi square and student's t-tests, and to assess the relationship between the variables Pearson's correlation analyses were used.

Results: Psychiatric diagnoses $(p=0.00)$ and behavioral problems $(p<0.01)$ were encountered more frequently in children with asthma. Although self-esteem levels of asthmatic children were similar to those of the control group, as maternal emotional expression increased, children tended to have lower self esteem levels $(r=-0.38, p=0.002)$. Maternal emotional expression levels were found to be higher in the asthma group $(p=0.006)$ and it showed positive correlation with the presence of psychopathology and behavioral problems in the children.

Conclusions: Although self-esteem was not directly affected by the presence of asthma, co-occurrence of psychiatric disorders, emotional and behavioral problems, and high maternal emotional expressiveness result in decreased self-esteem in children. (Turk Arch Ped 2010; 45: 144-9)

Key words: Asthma, child, expressed emotion, self-concept

Yazışma Adresi/Address for Correspondence: Dr. Sema Ölçer, Kayseri Kadın Doğum ve Çocuk Hastalıkları Hastanesi Mustafa Kemal Paşa Bulvarı, Kocasinan/Kayseri Tel.: +90 3523382149 Faks: +90 3523380253 E-posta: semaolcer79@yahoo.com

Geliş Tarihi/Received: 23.09.2009 Kabul Tarihi/Accepted: 22.01.2010 


\section{Giriş}

Çocukluk çağı kronik hastalıkları hızı bir fiziksel ve ruhsal gelişim süreci yaşayan çocukların yaşa uygun gelişimsel kazanımlarına engel olmaktadır (1). Bu süreçte aşılması gereken zorlukların başında çocuğun tedaviye uyum göstermesi, hem çocuk hem de ailenin hastalı̆̆ı kabullenmesi gelmektedir $(2,3)$.

Çocuklarda en sık karșılașılan kronik hastalık olan astım genetik zeminde, değişik derecelerde biyokimyasal, immünolojik, enfeksiyöz, fizyolojik ve psikolojik etmenler tarafından tetiklenen reaktif solunum yolu hastalığıdır. Bugün artık astım hastalığının gelişiminde ruhsal etkenlerin birinci derecede rolü olmadığı bilinmektedir. Bununla birlikte akut atak dönemleri veya hastalığın kronikleşmesi çocuk ve ailesinin ruhsal ve sosyal uyumunu önemli ölçüde etkilemekte hatta yaşam boyu sürebilmektedir (4). Astımlı çocuklarda davranışsal ve duygusal sorunlar sıkça görülmekte, genellikle hastalık şiddeti ile koşut olmaktadır (5).

"Kendilik" kişinin diğer bireylerden gelen geri bildirimlerle birlikte, yaşadığı deneyimlerle şekillenen kendisi hakkındaki bakış açısı olarak tanımlanabilir (6). Kendilik kavramının duygusal (pozitif benlik saygısı) ve bilişsel (kendilik algısı) olmak üzere iki bileşenden oluştuğu kabul edilmektedir (7). Kronik hastalıkların beden algısı ve kendilik kavramı üzerinde etkili olduğu gösterilmektedir. Fakat bu etkinin hastalığın tipi, seyri, süresi ve bireyin kişisel özellikleri ile ilişkili olduğu düşünülmektedir. Birçok araştırmada astımlı çocuklarda benlik saygısı düzeyinin sağlıklı veya başka kronik hastalığı olan çocuklardan farkIı olmadığı saptanmıştır $(8,9)$. Kronik hastalık varlığında çocukların psikososyal uyumsuzluk açısından sağlıklı çocuklara göre iki kat daha fazla risk taşıdığı da bilinmektedir (10). Burada en belirleyici etmen ailenin ișlevselliği ve çocuğun hastalığına nasıl uyum yaptığıdır. Ailenin çocuğun hastalığına bakışı, çocukta kendilik kavramının nasıl oluşacağını belirleyen en önemli etmenlerden biridir.

Duygu dışavurumu temelde bireylerin diğer kişilere intiyaç ve beklentilerini iletme yoludur. Kişilerarası iletişimin yoğun olarak yaşandığı ortamlardan biri de ailedir. Duygu dışavurumu, aile yaşamının duygusal niteliğinin bir göstergesi olarak kabul edilmekte, kontrolsüz ve yoğun duygu dışavurumuna maruz kalan bireyin yoğun sıkıntı yaşayacağı belirtilmektedir (11).

Astımdaki gece belirtilerinin varlığı, uzun süreli ilaç kullanımı, ataklar nedeniyle hastane yatışları annenin yaşamını da fiziksel ve psikososyal yönden olumsuz etkileyebilir (12). Astımlı çocukların annelerinde psikiyatrik belirtilerin özellikle de depresyon ve kaygı düzeyinin fazla olduğunu ve depresif annelerin astımlı çocuklarında hastalanma sıklığının daha yüksek olduğunu gösteren çalışmalar olsa da, annelerin duygu dışavurumunu inceleyen çaış̧maya rastlanmamıştır (13-17). Bu çalışmada, astımlı çocukların benlik saygıları ve annelerinin duygu dışavu- rum düzeylerinin değerlendirilmesi, ayrıca bu değişkenlerin çocuktaki duygusal ve davranışsal sorunlar ile ilişkisinin araştırılması planlanmıştır.

\section{Gereç ve Yöntem}

\section{Örneklem}

Çalışmaya Marmara Üniversitesi Hastanesi Çocuk Göğüs Hastalıkları polikliniğinde ayaktan takip edilmekte olan, klinik belirtiler ve solunum işlev testi bulgularına dayanılarak "Global Initiative for Asthma" (GINA) ölçütlerine göre astım tanısı konan 8-18 yaşları arasında 65 çocuk ve ergen alındı (18). Hastaların astım şiddeti Çocuk Göğüs Hastalıkları uzmanı tarafından GINA kılavuzuna göre değerlendirildi (18). Altta yatan diğer akciğer hastalı̆̆ı (bronşiektazi, kistik fibroz vb.), eşlik eden herhangi bir kronik hastalığı (nörolojik metabolik, genetik hastalık, immün yetersizlik vb.) veya zekâ geriliği olan hastalar çalışmaya alınmadı. Kontrol grubu, hasta çocuk polikliniğine başvuran, bilinen herhangi bir kronik hastalığı olmayan, tekrarlayıcı enfeksiyon, kronik öksürük, hırıltılı solunum öyküsü bulunmayan ve zekâ geriliği olmayan 76 çocuk ve ergenden oluşmaktaydı.

\section{Ölçüm araçları}

Çocuklar için duygulanım bozuklukları ve şizofreni görüșme çizelgesi- şimdi ve yaşam boyu versiyonuTürkçe versiyonu (ÇDŞG-ŞY-T): 6-18 yaşları arasındaki çocuk ve ergenlerin DSM-III ve DSM-IV (Diagnostic and statistical manual of mental disorders) tanı ölçütlerine göre geçmişteki ve şu andaki psikopatolojilerini saptamak amacıyla geliştirilmiş olan yarı yapılandırılmış bir tanı görüşmesidir. Anne/baba ve çocuğun kendisinden alınan bilgiler doğrultusunda, doktor kendi yargısını kullanır $(19,20)$.

Çocuk ve gençler için davranış değerlendirme ölçeği (ÇDDÖ): Ölçek 4-18 yaş grubu çocuk ve gençlerin sosyal yeterlik alanları ve sorun davranışlarını anne babalardan elde edilen bilgiler doğrultusunda değerlendirmek amacıyla geliştirilmiştir (21-24).

Piers-Harris'in çocuklarda öz kavramı ölçeği (PHÇÖKÖ): 9-20 yaşları arasındaki bireylerin kendilerine yönelik duygu, düşünce ve tutumlarını değerlendirmeyi amaçlayan öz bildirim ölçeğidir. Bireylerin zihinsel özellikleri, okul durumları, fiziksel görünümleri ve özellikleri, kaygı düzeyleri, sosyal beğenilirlik ya da gözde olma durumlarıyla ilgili neler hissettikleri değerlendirilmektedir $(25,26)$.

Duygu dışavurum ölçeği (DDÖ): Aile ortamı içimde bireye yönelen davranış ve tutumlara eşlik eden duygusal yoğunluğun ölçümünde kullanılmak üzere geliştirilmiştir (27).

İstatistiksel değerlendirme: Elde edilen veriler "SPSS 11.0" programı ile değerlendirildi. Gruplar karşılaştııılırken kategorik değișkenler için ki-kare, sürekli değișkenler için student's t testi kullanıldı. Değişkenler arası ilişkiler Pear- 
son bağıntı analizi ile incelendi. p değerinin 0,05'den küçük olması istatistiksel olarak anlamlı kabul edildi.

\section{Bulgular}

Astım grubunda 65, kontrol grubunda ise 76 çocuk ve ergen yer almaktaydı. Astımlı olguların \%60'ında ( $n=39)$ bulguların kontrolü kısmen sağlanmış durumdaydı. Olguların \%21,5'inin $(n=14)$ bulgu kontrolü tam olmasına karşın 12 olguda $(\% 18,5)$ bulgu kontrolü yoktu. Hastalık süresi ortalama 6,26 $\pm 3,6$ yıldı. Astım grubunun \%60'। $(n=39)$ kontrol grubunun \%59,2'si $(n=45)$ erkekti. Yaş ortalamaları astım grubunda 11,5 $\pm 2,5 \mathrm{yıl}$, kontrol grubunda ise $12 \pm 2,5$ yıldı. Yaş ve cinsiyet oranları açısından iki grup birbiriyle benzerlik gösteriyordu $(p>0,05)$ (Tablo 1$)$.

1- Grupların klinik değerlendirme ve ölçek puanları açısından karşılaştırılması

Klinik değerlendirme sonucunda astım grubunda psikiyatrik tanı alma sıklı̆ı $(\% 44,6)$ kontrol grubundan fazlaydı $(\% 33)(p=0,00)$. Astım ve kontrol grupları karşılaștırıldığında tanı alma oranları depresyon $(\% 4,6 / \% 1,3)$, kaygı bozukluğu (\%9,2/\%0), dikkat eksikliği hiperaktivite bozukluğu $(23,1 / \% 3,9)$, tik bozukluğu $(\% 10,7 / \% 1,3)$ ve diğer tanılar $(\% 10,7 / \% 2,6)$ şeklindeydi. Ayrıca kontrol grubunda tanı alan olguların tamamı tek tanılı iken astım grubunda olguların \%13,8'i (9/65) çoklu psikiyatrik tanı almaktaydı. Yedi olgunun ikişer, iki olgunun üçer tanı aldığı

Tablo 1. Astım ve kontrol gruplarının demografik özellikleri

\begin{tabular}{|c|c|c|c|}
\hline & $\begin{array}{l}\text { Astım } \\
(n=65)\end{array}$ & $\begin{array}{c}\text { Kontrol } \\
(n=76)\end{array}$ & $\begin{array}{c}\text { İstatistiksel test, } \\
\text { p değeri }\end{array}$ \\
\hline Yaş (orttss) & $11,5 \pm 2,5$ & $12 \pm 2,5$ & $t=0,801 p=0,424$ \\
\hline \multicolumn{4}{|l|}{ Cinsiyet (n) } \\
\hline $\begin{array}{l}\text { KIz } \\
\text { Erkek }\end{array}$ & $\begin{array}{l}26 \\
39\end{array}$ & $\begin{array}{l}31 \\
45\end{array}$ & $x^{2}=0,09 p=0,924$ \\
\hline
\end{tabular}

saptandı. Çocuk ve Gençler İçin Davranış Değerlendirme Ölçeği kullanılarak iki grup karşılaştııılığında astım grubunun toplam sorun puanlarının $(56,92 \pm 10,89)$ kontrol grubuna göre $(53,15 \pm 9,74)$ daha yüksek olduğu saptandı. Somatik sorunlar ve dikkat sorunları $(p<0,01)$, sosyal içe dönüklük, suça yönelik davranışlar, düşünce sorunları, diğer sorunlar ile içe dönük sorun puanı ve toplam puan için $(p<0,05)$ iki grup arasındaki fark istatistiksel olarak anlamlı bulundu (Tablo 2). Çocuk ve ergenlerin benlik saygısının değerlendirildiği PHÇÖKÖ puanları incelendiğinde astım grubu ortalaması 54,60 $\pm 10,90$ kontrol grubu ortalaması 55,10 $\pm 8,15$ olarak bulundu, gruplar arasında istatistiksel olarak anlamlı fark saptanmadı (Tablo 3). İi grup annelerin duygu dışavurum düzeyleri açısından karşılaştııılığında, astım grubundaki annelerin DDÖ ortalama toplam puanları $(15,43 \pm 4,36)$ kontrol grubundaki annelerin aldıkları toplam puanlardan $(13,35 \pm 4,44)$ daha yüksek bulundu $(p<0,05)$ (Tablo 4).

\section{2- İlișki analizleri}

Çocukların PHÇÖKÖ puanları ile ÇDDÖ'den alınan puanları arasındaki ilişki incelendiğinde her iki grup için de PHÇÖKÖ ile ölçülen benlik saygısı düzeyi ile ÇDDÖ içe dönük davranış, dışa dönük davranış ve toplam davranış sorunu puanı arasında ters ilișki saptanmıştır (tümü için $r=-0,25-0,50, p<0,05$ ) (Tablo 5). Duygu dişavurum ölçeği puanları ile psikiyatrik tanı, PHÇÖKÖ ve ÇDDÖ puanları arasındaki ilișki Tablo 6'da sunulmuştur. Astım grubunda psikiyatrik tanı alıyor olmakla DDÖ arasında olumlu ( $r=0,25, p=0,040)$, PHÇÖKÖ ile DDÖ arasında olumsuz ilişki saptandı $(r=-0,38, p=0,002)$. Kontrol grubunda ise anne DDÖ puanı ile çocuğun psikiyatrik tanı alması arasında olumlu ilișki mevcutken $(r=0,32, p=0,005)$, PHÇÖKÖ toplam puanı ile bağıntı gözlenmedi $(r=-0,21$, $\mathrm{p}=0,067)$. Anne duygu dışavurumu ile çocukların davranış sorunları ilişkisine bakıldığında her iki grupta da annelerin

Tablo 2. Çocuk ve gençler için davranış değerlendirme ölçeği T skorları

\begin{tabular}{|c|c|c|c|c|}
\hline & $\begin{array}{c}\text { Astım Grubu ( } n=65) \\
\text { ort } \pm S S\end{array}$ & $\begin{array}{c}\text { Kontrol }(n=76) \\
\text { ort } \pm S S\end{array}$ & $\mathbf{t}$ & p \\
\hline Sosyal içe dönüklük & $58,66 \pm 9,11$ & $55,44 \pm 9,45$ & 2,045 & 0,043 \\
\hline Somatik sorunlar & $60,80 \pm 9,43$ & $55,86 \pm 6,23$ & 3,709 & 0,000 \\
\hline Anksiyete-depresyon & $59,38 \pm 8,76$ & $57,98 \pm 7,49$ & 1,021 & 0,309 \\
\hline Sosyal sorunlar & $55,21 \pm 7,84$ & $54,40 \pm 7,05$ & 0,643 & 0,521 \\
\hline Düşünce sorunları & $59,55 \pm 8,70$ & $56,98 \pm 6,19$ & 2,037 & 0,050 \\
\hline Dikkat sorunları & $59,40 \pm 8,88$ & $55,56 \pm 7,03$ & 2,858 & 0,006 \\
\hline Suça yönelik davranışlar & $54,43 \pm 6,12$ & $52,36 \pm 3,76$ & 2,444 & 0,020 \\
\hline Saldırgan davranışlar & $55,00 \pm 7,51$ & $53,77 \pm 5,99$ & 1,075 & 0,293 \\
\hline Diğer sorunlar & $6,30 \pm 4,89$ & $4,80 \pm 3,71$ & 0,030 & 0,040 \\
\hline İçe dönüklük & $59,60 \pm 11,05$ & $56,06 \pm 9,93$ & $-1,998$ & 0,048 \\
\hline Dışa dönüklük & $52,07 \pm 9,79$ & $49,51 \pm 8,39$ & $-1,674$ & 0,096 \\
\hline Toplam sorun & $56,92 \pm 10,89$ & $53,15 \pm 9,74$ & $-2,166$ & 0,032 \\
\hline
\end{tabular}


duygu dışavurum düzeyi arttıkça çocukların içe dönük, dışa dönük ve toplam davranış sorun puanlarının arttığı saptandl.

\section{Tartışma}

Astımlı çocukların benlik saygısı ile annelerinin duygu dışavurum düzeylerinin değerlendirildiği bu çalışmada astım grubunda depresyon, kaygı bozukluğu, dikkat eksikliği hiperaktivite bozukluğu ve tik bozukluğu başta olmak üzere psikiyatrik tanı alma sıklığı kontrol grubuna göre anlamlı derecede fazla bulundu. Kronik hastalığa sahip kişilerin psikolojik sorunlar açısından daha riskli oldukları bilinmektedir. Yazın bilgisine bakıldığında da astım grubunun sağlıklı kontrollerle veya bir başka kronik hastalık

Tablo 3. Çocuklarda öz kavramı ölçeği toplam puan dağılımları

\begin{tabular}{|l|c|c|c|c|}
\hline & $\begin{array}{c}\text { Astım Grubu } \\
(\mathbf{n}=65) \text { ort } \pm \text { SS }\end{array}$ & $\begin{array}{c}\text { Kontrol } \\
(\mathbf{n}=76) \text { ort } \pm \text { SS }\end{array}$ & $\mathbf{t}$ & $\mathbf{P}$ \\
\hline PHÇÖKÖ & $54,60 \pm 10,90$ & $55,10 \pm 8,15$ & 0,314 & 0,754 \\
\hline
\end{tabular}

Tablo 4. Annelerde duygu dışa vurum düzeyi ölçeği toplam puan dağılımları

\begin{tabular}{|l|c|c|c|c|}
\hline & $\begin{array}{c}\text { Astım Grubu } \\
(\mathbf{n}=65) \text { ort } \pm S S\end{array}$ & $\begin{array}{c}\text { Kontrol } \\
(\mathbf{n}=76) \text { ort } \pm S S\end{array}$ & $\mathbf{t}$ & $\mathbf{P}$ \\
\hline DDÖ & $15,43 \pm 4,36$ & $13,35 \pm 4,44$ & $-2,785$ & 0,006 \\
\hline
\end{tabular}

Tablo 5. Piers Harris Puanları ile Davranış Değerlendirme Ölçeğinden alınan puanların korelasyonu

\begin{tabular}{|c|c|c|}
\hline & \multicolumn{2}{|c|}{ PHÇÖKÖ ${ }^{1}$ puanları } \\
\hline & Astım Grubu & Kontrol \\
\hline ÇDDÖ í² & $r=-0,36, p=0,003$ & $r=-0,39, p=0,000$ \\
\hline ÇDDÖ DD ${ }^{3}$ & $r=-0,42, p=0,001$ & $r=-0,25, p=0,028$ \\
\hline ÇDDÖ T ${ }^{4}$ & $r=-0,42, p=0,000$ & $r=-0,32, p=0,004$ \\
\hline
\end{tabular}

${ }^{1}$ PHCÖKÖ: Piers-Harris'in çocuklarda öz kavramı ölçeği

${ }^{2}$ ÇDDÖ ID: Çocuk ve gençler için davranış değerlendirme ölçeği içe dönük sorun puanı ${ }^{3}$ ÇDDÖ DD: Çocuk ve gençler için davranış değerlendirme ölçeği dışa dönük sorun puanı ${ }^{4}$ ÇDDÖ T: Çocuk ve gençler için davranış değerlendirme ölçeği toplam puanı

\begin{tabular}{|c|c|c|}
\hline & \multicolumn{2}{|c|}{ DDÖ puanları } \\
\hline & Astım Grubu & Kontrol \\
\hline Psikiyatrik tanı & $r=0,25, p=0,040$ & $r=0,32, p=0,005$ \\
\hline PHÇÖKÖ & $r=-0,38, p=0,002$ & $r=-0,21, p=0,067$ \\
\hline ÇDDÖ ID & $r=0,43, p=0,000$ & $r=0,40, p=0,000$ \\
\hline ÇDDÖ DD & $r=0,47, p=0,000$ & $r=0,53, p=0,000$ \\
\hline ÇDDÖ T & $r=0,47, p=0,000$ & $r=0,52, p=0,000$ \\
\hline
\end{tabular}

DDÖ: Duygu dışavurum ölçeği

PHÇÖKÖ: Piers-Harris'in çocuklarda öz kavramı ölçeği

CCDDÖ ID: Çocuk ve gençler için davranış değerlendirme ölçeği içe dönük sorun puan CCDDÖ DD: Çocuk ve gençler iccin davranıș değerlendirme ölcceği dıșa dönük sorun puanı

ÇDDÖ T: Çocuk ve gençler için davranış değerlendirme ölçeği toplam puanı grubu ile karşılaştııılığı görülmektedir. Bu çalışmaların bir kısmında diğer birçok kronik hastalıkta olduğu gibi astımlı çocukların sağlıklı çocuklara göre daha fazla psikiyatrik tanı aldıkları, özellikle kaygı bozukluklarının daha fazla saptandığı belirtilmekte bir diğer kısmında ise sağlıklı kontrollerle aralarında fark bulunmadığı ifade edilmektedir (28-33).

Çalışmamızda ÇDDÖ kullanılarak her iki grubun davranış sorunları incelendiğinde alt testler, içe dönük davranış sorun puanı ve toplam puan açısından astım grubunun puanları istatistiksel olarak fazlaydı. Bu doğrultuda çalışmamızdaki astımı olan çocukların kontrol grubuna göre daha fazla davranış sorunları gösterdikleri söylenebilir. Yazın bilgisinde astımı olan çocuklarda davranışsal zorlukların sağlıklı çocuklardan daha fazla olduğu, özellikle içe dönük davranışların dışa dönük davranışlara göre daha yüksek oranda görüldüğü ve astımın şiddeti artıkça davranış sorunlarının arttığı bildirilmektedir $(5,34,35)$.

Araştırmamızda çocuklarda benlik saygısı düzeyini ölçmek üzere kullanılan PHÇÖKÖ'den elde edilen puanlara bakıldığında iki grup arasında anlamlı fark bulunmadı. Yapılan çalışmaların pek çoğunda bizim sonuçlarımıza koşut olacak şekilde astım grubunun benlik saygısı düzeylerinin sağlıklı gruptan ya da diğer kronik hastalık grubundaki çocuklardan farklı olmadığı gösterilmiştir $(8,9,36)$. Diğer yandan astım şiddeti ile benlik saygısı düzeyi arasında ilişki gözlenmemiş olsa da psikiyatrik tanısı olan astımlılarda, olmayanlara göre daha düşük benlik saygısı ve daha zayıf sosyal uyum gözlendiği bildirilmiştir $(29,37)$.

Kistik fibrozu olan ergenlerle yapılan çalışmada astım ya da kanserli ergenlere göre kendilik imgeleriyle ilgili daha fazla zorluk yaşadıkları bildirilmiştir (38). Bu durum fiziksel görünümün etkilenmiş olmasının özellikle ergenlerin benlik saygısı düzeylerinde daha fazla etkiye sahip olabileceği şeklinde yorumlanmıştır. Öte yandan bazı araştırmacılar astım grubu ile benzer şekilde kanser, diyabet ve işitme engelli çocukların da benlik saygısı düzeylerinin sağlıklı kontrollerden farklı olmadığını saptamışlardır (36).

Astımda aile işlevlerinin önemi uzun zamandır bilinmektedir (39-41). Ebeveynler arası iletişimin niteliği ve çocuk-ebeveyn ilişkisinin güvenliği çocukta astım şiddetini etkileyen etmenlerdir (42). Ailesel çatışmaların ve öfke dışavurumunun yoğunluğu ile hastaneye yatış sıklığı arasında belirgin bir ilișki saptanması, ebeveynlerinin eleştirel tutumu fazla olan ergenlerde hastane yatışı sırasında onlardan ayrı tutulduklarında tedavi yanıtının daha iyi olması bu bulguları destekler niteliktedir $(34,43,44)$. Bu durum biyolojik olarak, depresif duygudurumun otonom sinir sisteminde düzensizliğe ve nervus vagus aracılığılla hava yolunda daralmaya yol açarak hastalığın şiddetini arttırdığı şeklinde açıklanmaktadır (42). 
Araştırmamızda astımlı grupta annelerin duygu dışavurum düzeyi belirgin olarak yüksekti. Ayrıca çocukların benlik saygı düzeyi ile arasında olumsuz ilişki saptandı. Her iki grup için de anne duygu dişavurumunun çocuklardaki psikiyatrik tanı varlığı ile doğrudan ilişkili olduğu görülmüştür (Grafik 1). Bu durum kronik hastalık söz konusu olsun ya da olmasın psikolojik sorunlarla anne duygu dışavurumunun karşılıklı etkileşim halinde olduğunu düşündürmektedir.

Yapılan çalışmalarda annenin stres düzeyinin çocukların davranışlarını algılama biçimini etkilediği, gerginliği fazla olan annelerin çocuklarında daha fazla davranış sorunları bildirdikleri saptanmıştır (45). Davranış sorunları olan çocuklarda annenin huzursuz ve keyifsiz olmasının kontrolü sağlamada zorluğa neden olduğu; bu durumun çocuklardaki tepkisel davranışların bir bölümünden sorumlu olabileceği belirtilmiştir (46).

Sonuç olarak kronik hastalıkla yaşamak ve bu hastalığa uyum sağlayabilmek hem çocuk hem de ailesi için güçtür. Tedavi sürecindeki tıbbi müdahalelerin ve hastaIığın oluşturduğu engellemelerin zorluklarına katlanmak çocukta ruhsal gerginlik oluşturmaktadır. Fiziksel hastalığa eşlik eden davranışsal ve ruhsal sorunlar, hastanın tedaviye uyumunu, dolayısıyla da hastalığın seyrini olumsuz etkilemektedir. Araştırmamızda astımlı çocuklarda psikiyatrik tanı alma, çeşitli davranış sorunları yaşama oranları ve annelerinin duygu dışavurum düzeyleri kronik hastalığı olmayan çocuklara göre daha yüksek saptanmıştır. Astım genel olarak çocuklarda benlik saygısını etkilememekle birlikte hastalığa ikincil gelişen duygusal ve davranışsal sorunlar, eş tanı olarak görülen psikiyatrik bozukluklar, annelerin duygu dişavurumunun fazla olması çocuğun benlik saygısını olumsuz etkilemektedir. Annelerin duygu ifadelerinin kronik hastalıktan bağımsız olarak psikiyatrik sorunun varlığı ile doğrudan ilişkili olduğu gözlenmiştir.

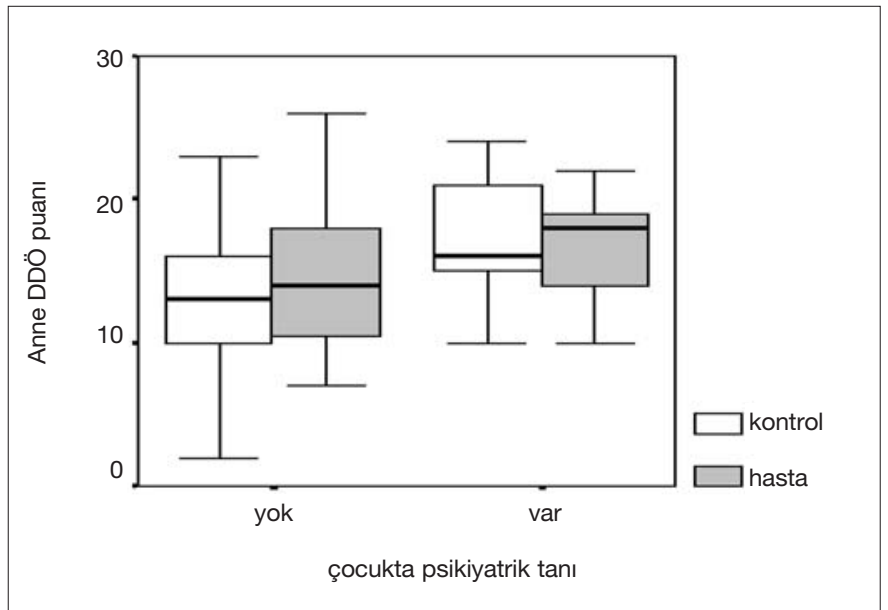

Grafik 1. Psikiyatrik tanı alma sıklığı ile anne duygu dışavurum düzeyi arasındaki ilişki
Çalışmamızda astım şiddeti hafif olan olgular ağırlıkta olduğundan genelleme yapabilmek ve bahsedilen değişkenlerin hastalık şiddeti ile ilişkisini irdelemek için daha geniş örneklemli çalışmalara ihtiyaç vardır. Ayrıca kronik hastalığa sahip çocuklarda, bir çevresel stres etkeni olarak, anne duygu dişavurumuna benzer şekilde, aile içi ilişkilenme biçimlerine odaklanan daha kapsamlı araştırmalar yapılması çevresel stres ve genetik yatkınlık arasındaki karşılıklı etkileşimin aydınlatılmasına katkıda bulunacaktır.

Çocukluk çağının en sık görülen kronik hastalığı olan astımın tedavi sürecinde çocuk ve ailesinde oluşabilecek ruhsal sorunların doktorlar tarafından erken tanınması ve gerekli girişim için yönlendirilmesi oldukça önemlidir. Zamanında ve uygun girişim hem hastalığın seyrine olumlu yönde katkı sağlayacak hem de ruhsal sorunların erken çözülmesine yardımcı olacaktır.

\section{Kaynaklar}

1. Steiner H. Chronic Illness and physical disabilities. In: Noshpitz JD (ed). Handbook of Child and Adolescent Psychiatry. New York: John Wiley\&Sons, 1997: 251-73.

2. Wasserman AL. Principles of Psychiatric Care of Children and Adolescents With Medical Illnesses. In: Barry D Garfinkel, Gabriella A Carlson, Elizabeth B Weller (eds). Psychiatric Disorders in Children and Adolescents. Philadelphia: W.B. Saunders Company, 1990: 486-502.

3. Boekaerts M, Röder I. Stress, coping and adjustment in children with a chronic disease: a review of the literature. Disabil Rehabil 1999; 21: 311-37. (Abstract)

4. Ekși A. Ben hasta değilim. Çocuk Sağlığı ve Hastalıklarının Psikososyal Yönü kitabı. İstanbul: Nobel Tıp Kitabevleri, 1999; 50-69.

5. McQuaid EL, Kopel SJ, Nassau JH. Behavioral adjustment in children with asthma: a meta-analysis. J Dev Behav Pediatr 2001; 22: 430-9. (Abstract)

6. Shavelson RJ, Hubner JJ, Stanton GC, et al. Self-concept: validation of construct interpretations. Rev Educ Res 1976; 46: 407-41. (Abstract)

7. Pumariega AJ, Pearson DA, Seilheimer DK. Family and childhood adjustment in cystic fibrosis. J Child Fam Stud 1993; 2 : 109-18. (Abstract) / (PDF)

8. Siegel WM, Golden NH, Gough JW, Lashley MS, Sacker IM. Depression, self esteem, and life events in adolescents with chronic diseases. J Adolesc Health Care 1990; 11: 501-4. (Abstract)

9. Nelms BC. Emotional behaviors in chronically ill children. $J$ Abnorm Child Psychol 1989;17: 657-68. (Abstract)

10. Pless IB. Clinical assessment: physical and psychological functioning. Pediatr Clin North Am 1984; 31: 33-45. (Abstract)

11. Dattilio FM, Epstein NB. Cognitive-Behavioral Couple and Family Therapy. Thomas LS, Gerald RW, Michael SR (eds). Handbook of Family Therapy: The Science and Practive of Working with Families and Couples. Brunner-Routledge, NY, 2003; 155-6.

12. Yüksel H, Söğüt $A$, Yılmaz Ö, Demet $M$, Ergin D. Astımlı çocukların annelerinde uyku kalitesi ve anksiyete-depresyon parametrelerinin değerlendirilmesi. Astım Alerji İmmünoloji 2007; 5: 67-71. (PDF)

13. Shalowitz MU, Mijanovich T, Berry CA, et al. Context matters: a community based study of maternal mental health, life stressors, social support, and children's asthma. Pediatrics 2006; 117: 940-8. (Abstract) / (PDF) 
14. Berkem M, Arman A, Dağlı E, Hayran O. Bronşiyal astım tanısı alan çocuklar ve annelerinde hastalık algısının değerlendirilmesi. Çocuk ve Ergen Ruh Sağlığı Dergisi 1995; 2: 63-9. (Abstract)

15. Bartlett SJ, Kolodner K, Butz AM, Eggleston P, Malveaux FJ, Rand CS. Maternal depressive symptoms and emergency department use among inner-city children with asthma. Arch Pediatr Adolesc Med 2001; 155: 347-53. (Abstract) / (Full Text) / (PDF)

16. Bartlett SJ, Krishnan JA, Riekert KA, Butz AM, Malveaux, FJ, Rand CS. Maternal depressive symptoms and adherence to therapy in inner-city children with asthma. Pediatrics 2004; 113: 229-37. (Abstract) / (Full Text) / (PDF)

17. Klinnert MD. Psychosocial influences on asthma among innercity children. Pediatr Pulmonol 1997; 24: 234-6. (Abstract) / (PDF)

18. GINA (Global Initiative for Asthma) 2006, Küresel Astım Önleme ve Tedavi Girişimi 2006. Çeviri editörü: Türktaş H. İstanbul: Turgut Yayıncılık, 2007: 22-3.

19. Kaufman J, Birmaher B, Brent D, Rao U, Ryan N. KiddieSchedule for affective disorders and schizophrenia for school aged children-present and life time version (K-SADS-PL, 1.0 version), 1996.

20. Gökler B, Ünal F, Pehlivantürk B, Çengel Kültür E, Akdemir D, Taner Y. Okul çağı (6-18 yaş) çocukları için duygulanım bozuklukları ve şizofreni görüşme çizelgesi-şimdi ve yaşam boyu versiyonunun Türkçe uyarlamasının geçerlik ve güvenirliği. Çocuk ve Gençlik Ruh Sağlığı Dergisi 2004; 11: 109-16.

21. Achenbach TM, Edelbrock CL. Manual for the child behavior checklist and revised child behavior profile. Burlington, VT, University of Vermont Department of Psychiatry 1983.

22. Akçakın M. Çocukların davranışlarını değerlendirme ölçeği tanıtımı ve güvenilirlik çalışması. Psikoloji Dergisi 1985; 5: 3-6. (Abstract)

23. Erol N, Şimşek Z. Türkiye ruh sağlığı profili. Çocuk ve gençlerde ruh sağlığı yeterlik alanları, davranış ve duygusal sorunların dağılımı. Derleyen: Erol N, Kılıç C, Ulusoy M, Keçeci M, Şimşek Z. Türkiye Ruh Sağlığı Profili: Ön Rapor, Ankara: Aydoğdu Ofset, 1997.

24. Erol N, Arslan BL, Akçakın M. The adaptation and standardization of the Child Behavior Checklist among 6-18 year-old Turkish children. In: Sergeant J (ed), Eunethydis. European approaches to hyperkinetic disorders. Zurich: Fotoratar, 1995: 97-113.

25. Piers EV. Piers-Harris Children's Self-Consept Scale (The Way I Feel About Myself) Revised Manual. Los Angeles: CA, Western Psychological Services, 1984.

26. Öner N. Piers-Harris'in çocuklarda öz kavramı ölçeği: El kitabı. Ankara: Türk Psikologlar Derneği Yayınları, 1996.

27. Berksun OE, Soykan A, Ünal S, Ünlüoğlu G, Soykan Ç. Şizofrenide aile faktörü 'Expressed Emotion'la ilgili bir ölçek denemesi. Ankara Tıp Mecmuası 1992; 45: 637-46.

28. Mrazek D, Anderson I, Strunk R. Disturbed emotional development of severely asthmatic preschool children. In: Stevenson $\mathrm{J}$ (ed). Recent research in developmental psychopathology. J Child Psychol Psychiatry 1985; 4: 81-94.

29. Vila G, Nollet-Clemençon C, Vera M, et al. Prevalence of DSM-IV disorders in children and adolescents with asthma versus diabetes. Can J Psychiatry 1999; 44: 562-9. (Abstract)
30. Bussing R, Burket RC. Anxiety and intrafamilial stress in children with hemophilia after the HIV crisis. J Am Acad Child Adolesc Psychiatry 1993; 32: 562-7. (Abstract)

31. Ortega AN, Huertas SE, Canino G, Ramirez R, Rubio-Stipec M. Childhood asthma, chronic illness, and psychiatric disorders. J Nerv Ment Dis 2002; 90: 275-81. (Abstract) /

32. Steinhausen HC, Schindler HP, Stephan H. Comparative psychiatric studies on children and adolescents suffering from cystic fibrosis and bronchial asthma. Child Psychiatry Hum Dev 1983; 14: 117-30. (Abstract) / (PDF)

33. MacLean WE Jr, Perrin JM, Gortmaker S, Pierre CB. Psychological adjustment of children with asthma: effects of illness severity and recent stressful life events. J Pediatr Psychol 1988; 17:159-71. (Abstract)

34. Wamboldt MZ, Fritz G, Mansell A, McQuaid EL, Klein RB. Relationship of asthma severity and psychological problems in children. J Am Acad Child Adolesc Psychiatry 1998; 37 : 943-50. (Abstract)

35. Ekşi A, Molzan J, Savaşır I, Nermin G, İplikçioğlu Ö. Astımlı çocuk ve adolesanlarda psikolojik uyum. Türk Psikiyatri Dergisi 1996;7: 101-6. (Abstract)

36. Harter Susan. The construction of the self: a developmental perspective. Guilford Press, NY, 1999.

37. Vila G, Nollet-Clemencon C, de Blic J, Mouren-Simeoni MC, Scheinmann P. Asthma severity and psychopathology in a tertiary care department for children and adolescent. Eur Child Adolesc Psychiatry 1998; 7: 137-44. (Abstract)

38. Offer D, Ostrov E, Howard Kl. Body image, self perception and chronic illness in adolescence. In: Blum RW (ed). Chronic illness and disabilities in childhood and adolescence. Orlando: FL: Grune \& Stratton. 1984: 59-73.

39. Minuchin S, Baker L, Rosman BL, Liebman R, Milman L, Todd TC. A conceptual model of psychosomatic illness in children: family organization and family therapy. Arch Gen Psychiatry 1975;32:1031-8. (Abstract) / (PDF)

40. Mrazek DA. Chronic pediatric illness and multiple hospitalizations in child and adolescent psychiatry. A Comprehensive Textbook. Lewis M (ed). Baltimore: Williams\&Wilkins, A Waverly Company, 1996: 1058-10.

41. Mrazek DA, Schuman WB, Klinnert M. Early asthma onset: risk of emotional and behavioral difficulties. J Child Psychol Psychiatry 1998; 39: 247-54. (Abstract)

42. Wood BL, Miller BD, Lim J, et al. Family relational factors in pediatric depression and asthma: pathways of effect. $\mathrm{J} \mathrm{Am}$ Acad Child Adolesc Psychiatry 2006; 45: 1494-502.

43. Chen E, Bloomberg GR, Fisher EB Jr, Strunk RC. Predictors of repeat hospitalizations in children with asthma: the role of psychosocial and socioenvironmental factors. Health Psychol 2003; 22: 12-8. (Abstract) / (Full Text) / (PDF)

44. Chen E, Fisher EB, Bacharier LB, Strunk RC. Socioeconomic status, stress, and immune markers in adolescents with asthma. Psychosom Med 200; 65: 984-2. (Abstract) / (Full Text) / (PDF)

45. Thompson RJ, Gustafson KE. Adaptation to chronic childhood illness. Washington, DC: American Psychological Association 1996: 157-76.

46. Hetherington E, Martin B. Family factors and psychopathology in children. In: Quay H, and Werry J (eds). Psychopathological disorders of childhood. 3rd edition. New York: Wiley, 1986: 332-90. 